J. Perinat. Med. 16 (1988) 61

\section{Longitudinal follow-up of 100 patients at risk of intrauterine growth retardation: comparison of diagnosis in two periods}

\author{
María Cristina Cordano ${ }^{1,2}$, Elizabeth Comte ${ }^{1}$, Roger Bessis ${ }^{1}$, and Emile Papiernik ${ }^{1}$ \\ ${ }^{1}$ Service of Obstetrics and Gynecology, Hôpital Antoine Béclère, Clamart, France \\ ${ }^{2}$ Latin American Center for Perinatology and Human Development (CLAP - OPS/ \\ OMS), Montevideo, Uruguay
}

\section{Introduction}

Low birth weight newborns are one of the major problems in world public health $[9,22]$. In 1979, 21 million low birth weight infants were born, i.e., $17 \%$ of the world's newborns in that year. Perinatal mortality of these infants is 6-10 times greater than of those with appropriate weight and born at term. Low birth weight includes: 1) Intrauterine growth retardation which is 6 times higher in underdeveloped countries [21], and 2) Premature infants with a similar incidence in developed and underdeveloped countries [21].

Clinical methods are only useful to diagnose a low percentage of intrauterine growth retardation (IUGR) [20]. With the measurement of fetal diameters and circumferences by ultrasound, it is possible to enhance the percentage of diagnosis $[12,16]$ and to classify IUGR into symmetric and asymmetric $[3,13]$. The objectives of this study are:

- to evaluate efficacy of different fetal anthropometric measurements, both clinical and sonographic for the diagnosis of IUGR;

- to identify symmetric and asymmetric IUGR's by means of ultrasonic parameters;

- to evaluate the effect of the use of fetal circumference measurements in the IUGR ultrasonic diagnosis studied in two periods: a period before and a period after the adoption of these measurements; and

- to compare the clinical and ultrasonic diagnoses in the above mentioned periods.

\section{Curriculum vitae}

Maria Cristina CorDANO was born in Montevideo, Uruguay, in 1946. She received the Doctor of $\mathrm{Me}$ dicine degree from the School of Medicine, University of Uruguay, in 1976. In 1973-1982 she did research at the Latin American Center for Perinatology and Human Development, Montevideo,

Uruguay. In 1977-1978 she was a Research Fellow at the same Center. In 1981 her thesis on "Fetal growth in twin pregnancies" was approved. In 1982-1983 under contract by INSERM for foreign investigators she worked at the Antoine Béclère Hospital, France, which is directed by Dr. EMILE PAPIERNIK. In 1983 she obtained Board certification in Obstetrics-Gynecology. She has worked at the Uruguayan Center for Perinatology at the Perinatal Ultrasound Laboratory since 1980.

\section{Material and methods}

Until 1982, clinical criteria for the diagnosis of IUGR used at the Antoine Béclère Hospital were uterine height, weight and clinical assessment on palpation, while the ultrasonic criteria were biparietal diameter (BPD) and transverse abdominal diameter (TAD). After 1982, new ultrasonic criteria were introduced: head circumference, abdominal circumference and head circumference/abdominal circumference ratio. IUGR was dia- 
gnosed when any of these measurements was below $\mathrm{P}_{5}$ of the expected values for gestational age. Clinical criteria for IUGR diagnosis remained unmodified. One hundred pregnant women with single gestation and date of last menstruation which was certain or else confirmed by early ultrasound, were longitudinally followed. They had to comply with one or more of the following requirements: maternal disorders that could cause IUGR, history of fetuses with IUGR and clinical suspicion of IUGR.

Patients were evaluated every 15 days with a B mode dynamic Toshiba echograph, using a frequency of $3.5 \mathrm{~m} \mathrm{~Hz}$ and a velocity setting of 1540 meters per second. The following parameters were measured: BPD, fronto-occipital diameter (FOD), anterior-posterior abdominal diameter (APAD), transverse abdominal diameter (TAD), head circumference $(\mathrm{HC})$ /abdominal circumference ratio (AC), femur length. Techniques used for ultrasonic measurements of BPD, FOD, APAD, TAD, $\mathrm{HC}$ and $\mathrm{AC}$, are those described by FESCINA et al. $[6,7]$. The femur was measured following O'BRIEN and QUEENAN's technique $[17,18]$. Sensitivity, specificity and predictive values of the above mentioned ultrasonic parameters were calculated. All newborns with birth weight below $\mathrm{P}_{10}$ from the Leroy-Lefort curve were considered small for gestational age (SGA) [14, 15].

Of the 51 SGA infants, 28 were symmetric and 23 asymmetric. The intrauterine ultrasound measurement that more accurately predicted each retardation variety was analyzed in this group. At the same time, 116 clinical histories of IUGR births which had taken place at the same hospital during the first half of 1982 were analyzes*. The clinical and ultrasonic diagnosis, and the ultrasonic parameters on which the diagnosis was based, were studied. The clinical and ultrasonic diagnosis of both periods were then compared. The groups were contrasted with either the ordered Chi Square or the Fisher's exact test was used with an alpha significance level of $5 \%$.

\section{Results}

Newborns of the 100 patients in the prospective study were classified into two groups according to birth weight. This demonstrated that 49 newborns were AGA and 51 were SGA. Fifty-nine percent of

\footnotetext{
* Only BPD and TAD were measured in this group.
}

the SGA infants had a prenatal clinical diagnosis. Ultrasonic diagnosis had been made in $100 \%$ of cases (table I). Of the 49 AGA newborns, 6 were falsely positive by ultrasound criteria. Diagnostic analyses result in $100 \%$ sensitivity and $88 \%$ specificity when fetal abdominal circumference is used for such analyses. When the $\mathrm{HC} / \mathrm{AC}$ ratio was analyzed, IUGR infants were classified into symmetric and asymmetric. Of the 28 symmetric fetuses, a correct in utero diagnosis for the type

Table I. Analysis of sensitivity, specificity and predictive previous values (PPV) of the diagnosis of IUGR using ultrasonographic abdominal perimeter.

\begin{tabular}{lccr}
\hline $\begin{array}{l}\text { Abdominal perimeter } \\
\text { by ultrasound }\end{array}$ & IUGR & AGA \\
\hline IUGR & 51 & 6 & 57 \\
AGA & 0 & 43 & 43 \\
& 51 & 49 & 100 \\
\hline Sensitivity $=100 \%$ & PPV $\oplus=89,4 \%$ \\
Specificity $=88 \%$ & PPV $\ominus=100 \%$ \\
\hline
\end{tabular}

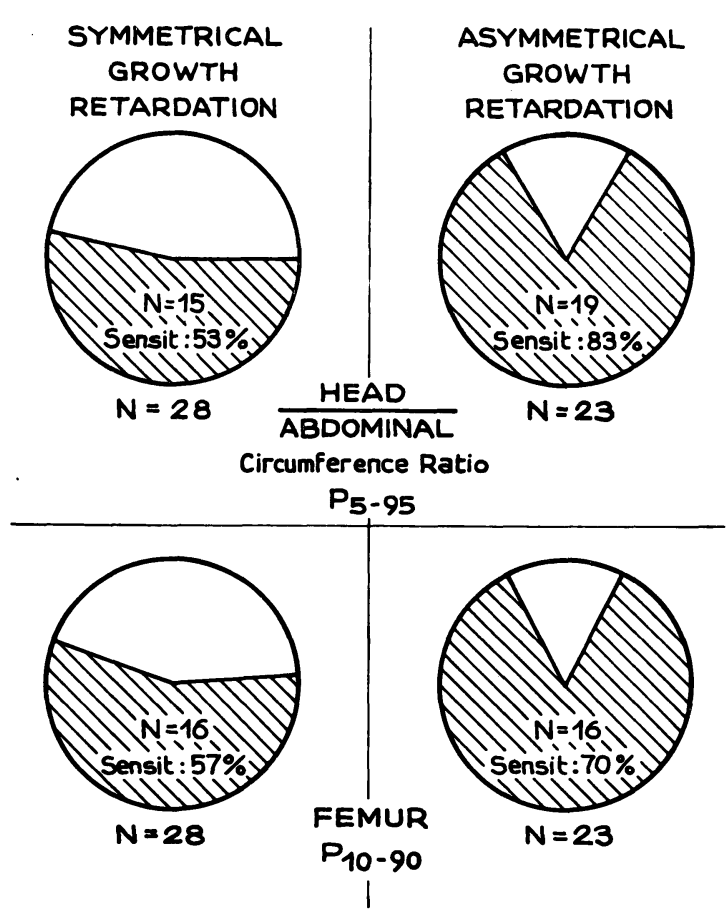

Figure 1. Analysis of ultrasound efficiency for the difference between the diagnoses of symmetric and asymmetric IUGR based upon head/abdominal circumference ratio and femur length. 
of retardation was made in 15 fetuses with a sensitivity of $53 \%$. Of the 23 asymmetric fetuses a correct diagnosis was made in 19 with an $83 \%$ sensitivity (figure 1). The sensitivity of the femur method is similar to that of the $\mathrm{HC} / \mathrm{AC}$ ratio, although the latter's sensitivity is greater for the diagnosis of asymmetric IUGR. The comparison of both diagnostic periods and the analysis of the clinical and ultrasonic data shows the following results (table II): the clinical diagnosis is $27 \%$ accurate in the first period and $59 \%$ in the second period; the sensitivity of the ultrasonic diagnosis using fetal circumferences (particularly the analysis of the abdominal circumference) increases from $58 \%$ to $100 \%\left(\chi^{2} \leqslant 0.05\right)$.

In table III the value of the different ultrasonic parameters for the diagnosis of IUGR in both periods is analyzed. No significant differences

Table II. Comparison of the two periods of IUGR diagnosis. Analysis of the accuracy of clinical and ultrasound diagnosis in both periods.

\begin{tabular}{|c|c|c|c|c|c|}
\hline \multirow[t]{2}{*}{ Diagnosis } & \multicolumn{2}{|c|}{ First period } & \multicolumn{2}{|c|}{ Second period } & \multirow[t]{2}{*}{$\chi^{2}$} \\
\hline & $\mathrm{N}$ & $\%$ & $\mathbf{N}$ & $\%$ & \\
\hline $\begin{array}{l}\text { Clinical and } \\
\text { ultrasound }\end{array}$ & $56 / 116$ & 49 & $51 / 51$ & 100 & $\begin{array}{l}26,5 \\
\text { sign. }\end{array}$ \\
\hline Clinical & $31 / 116$ & 27 & $30 / 51$ & 59 & $\begin{array}{l}14,3 \\
\text { sign. }\end{array}$ \\
\hline Ultrasound & $35 / 60$ & 58 & $51 / 51$ & 100 & $\begin{array}{l}22,07 \\
\text { sign. }\end{array}$ \\
\hline
\end{tabular}

Table III. Analysis of the value of different ultrasonographic parameters in the diagnosis of IUGR. Comparison of both periods studied.

\begin{tabular}{|c|c|c|c|c|c|}
\hline \multirow[t]{2}{*}{ Parameters } & \multicolumn{2}{|c|}{ First period } & \multicolumn{2}{|c|}{ Second period } & \multirow[t]{2}{*}{$\chi^{2}$} \\
\hline & $\mathbf{N}$ & $\%$ & $\mathrm{~N}$ & $\%$ & \\
\hline Ultrasound & $35 / 60$ & 58,3 & $51 / 51$ & 100 & $\begin{array}{l}22,07 \\
\text { sign. }\end{array}$ \\
\hline $\begin{array}{l}\text { Biparietal } \\
\text { diameter }\end{array}$ & $24 / 35$ & 68,5 & $30 / 51$ & 59 & $\begin{array}{r}0,47 \\
\text { N.S. }\end{array}$ \\
\hline $\begin{array}{l}\text { Transversal } \\
\text { abdominal } \\
\text { diameter }\end{array}$ & $6 / 35$ & 17,6 & $13 / 51$ & 25 & $\begin{array}{l}0,43 \\
\text { N.S. }\end{array}$ \\
\hline $\begin{array}{l}\text { Abdominal } \\
\text { perimeter }\end{array}$ & & & $51 / 51$ & 100 & \\
\hline
\end{tabular}

were found between both periods for the diagnostic percentage obtained with diameters alone. The use of circumference measurements is responsible for a $100 \%$ accuracy of diagnosis.

\section{Discussion}

Longitudinal studies describe growth in each individual, and are the only appropriate studies to evaluate fetal growth and its deceleration. The advantage of head and abdominal circumferences over diameters are stated by various authors [1, $2,5,8,10,11]$. PAPIERNIK has demonstrated the importance of abdominal parameters over head parameters [19]. $\mathrm{HC}$ is a more faithful indicator than BPD, particularly in cases of dolichocephalic fetuses, where false IUGR diagnosis may be made. On the other hand, the TAD has certain important variations due to the absence of osseous content of the abdomen and the presence of fetal respiratory movements. AC is a good indicator of in utero fetal loss of weight at the expense of the abdominal adipose layer and of liver involvement as reported by CAMPBELL [2]. This author also asserts that $\mathrm{AC}$ is the most representative indicator of total fetal weight [4]. In this sense, the present paper supports these findings. Using AC, the correct IUGR ultrasonic diagnosis goes from $58 \%$ in the first period to $100 \%$ in the second one. Upon analyzing ultrasonic diagnosis based on diameters, we observe that $59 \%$ of accurate diagnosis are achieved with BPD, and $25 \%$ when the TAD is used. The chief contribution of this paper consists in reporting that the percentage of accuracy for the diagnosis of IUGR increases when diameters are substituted by fetal circumferences.

A second point worth analysis is the accuracy of clinical diagnosis of IUGR in both periods. It goes from $27 \%$ in the first stage to $50 \%$ in the second one. This must be partly due to the fact that $40 \%$ of patients longitudinally followed up in the second period came from a specialized outpatient clinic (arterial hypertension) and were evaluated every 15 days. This fact is a deficiency of the design of the present study. The percentage of accurate clinical diagnosis in the second period $(59 \%)$ shows the value of clinical assessment particularly in those places where ultrasonic followup is not possible. This agrees with conclusions reported by PAPIERNIK [19].

Regarding the discriminatory diagnosis between symmetric and asymmetric IUGR, we stress the 
importance of the HC/AC ratio. The femur follows next in order of importance (figure 1).

In a study of symmetric IUGR O'BRIEN and QUEENAN [17] found that femur values below the tenth percentile could be used when $\mathrm{HC}$ cannot be measured. This statement is supported by the results shown in figure 1 . The femur method may be useful for services that have ultrasonographic unity with transducers that, because of their size, are not suitable to measure the FOD, and HC can therefore not be calculated.

Newborns with an ultrasonic false positive diagnosis of IUGR were long and had the appearance of being hypotrophic at birth. This fact suggests that:

1. There had been an actual in utero loss of weight of those fetuses considered to be normal at birth.

2. The concept of the newborn with appropriate growth for its gestational age, currently defined as below the tenth percentile for weight curve versus gestational age only, should be revised.

3. It should be possible to add fetal length as an indicator to the abdominal circumference in order to improve the prediction of fetal weight by ultrasound.

\section{Summary}

The concept of low birth weight includes two different entities: prematurity and intrauterine growth retardation. Both of them are major public health problems, because they increase perinatal morbidity and mortality [22]. Early diagnosis of IUGR leads to adequate decisions, making possible a reduction in perinatal morbidity and mortality. In order to make an early diagnosis of IUGR, clinical methods have proven to be insufficient. Ultrasonography is an important aid to this diagnosis, introducing the measurement of fetal diameters and perimeters. This study, designed to compare both methods, was carried out in at the Antoine Béclère Hospital, Clamart, France. Data processing was done in CLAPPAHO/WHO.

In the first period, retrospective analyses of 116 clinical histories with IUGR were performed. In this study, only fetal diameters were used and the accuracy of clinical and ultrasonographic diagnosis was evaluated. In the second period a prospective longitudinal follow-up study of 100 pregnant women at risk of developing IUGR was carried out. Clinical diagnosis was also evaluated, and compared to the ultrasonographic approach. The parameters used were the fetal diameters and perimeters (head and abdominal perimeters, and their relationship). Sensitivity, specificity and predictive values of the ultrasonic parameters were calculated (table I).

The clinical and ultrasonographic diagnosis of both

periods were compared with the purpose to analyze the effect of the measurement of fetal perimeters in the diagnostic accuracy. Newborns of the 100 patients in the prospective study were classified into two groups according to birth weight. All newborns with a birth weight below P10 in the Leroy-Lefort curve were considered small for gestational age (SGA). The results included 49 newborns with appropriate weight and 51 small for gestational age infants (SGA). Fifty-nine percent of the 51 SGA infants had a prenatal clinical diagnosis. Ultrasonic diagnosis had been made in $100 \%$ of cases. Of the 49 adequate for gestational age (AGA) newborns, 6 were false positives using ultrasound criteria. Diagnostic analyses demonstrated $100 \%$ sensitivity and $88 \%$ specificity when the fetal abdominal circumference is used for ultrasound analysis (table I).

If we compare both diagnostic periods and analyze the clinical and ultrasonic data, we obtain the following results (table II): the clinical diagnosis was $27 \%$ in the first period and $59 \%$ in the second period; the ultrasonic diagnosis, using fetal circumferences - particularly the analysis of the abdominal circumference, increases the accuracy of the method from $58 \%$ to $100 \%$ (significant Chi Square Test). The diagnostic percentage obtained with ultrasonic diameters is the same for both periods. The use of circumference measurements is responsible for the increase in the accuracy of the method.

Keywords: Abdominal perimeters, clinical diagnosis, intrauterine growth retardation, ultrasonic diagnosis.

\section{Zusammenfassung}

Prospektive Studie an 100 Patientinnen mit dem Risiko einer intrauterinen Wachstumsretardierung: Vergleich der Diagnosen in zwei Perioden

Der Begriff des niedrigen Geburtsgewichts umfaßt zwei Gruppen: die Frühgeburtlichkeit und die intrauterine Wachtumsretardierung (IUGR). Beide Gruppen stellen ein großes Problem für die Volksgesundheit dar, denn sie erhöhen die perinatale Morbidität und Mortalität [22]. Die frühzeitige Diagnose der intrauterinen Wachstumsretardierung führt $\mathrm{zu}$ adäquaten Entscheidungen und ermöglichen so eine Reduzierung der perinatalen Morbidität und Mortalität. Klinische Parameter haben 
sich in der Frühdiagnose des IUGR als insuffizient erwiesen. Die Ultraschalldiagnostik hat sich als wichtige Untersuchung einen Platz geschaffen, da sie die Messung von fetalen Durchmessern und Umfängen erlaubt. Diese Studie will die beiden Methoden, die Umfangmessung und die alleinige Messung von Durchmessern, vergleichen. Sie wurde am Antoine Béclère Krankenhaus, Clamart, Frankreich, durchgeführt. Die Daten wurden bei der CLAP-PAHO/WHO verarbeitet.

Die erste Periode bestand aus einer retrospektiven Analyse von 116 Krankengeschichten mit IUGR. In dieser Studie wurden nur fetale Durchmesser bestimmt, und die Genauigkeit der klinischen und Ultraschall-Diagnosen wurden überprüft. In der zweiten Periode wurde eine prospektive Studie an 100 schwangeren Frauen durchgeführt, bei denen das Risiko einer IUGR bestand. Die klinische Diagnose wurde mit dem Ultraschall überprüft und verglichen. Als Parameter wurden die fetalen Durchmesser und Umfänge benutzt (Umfänge von Kopf und Abdomen sowie deren Verhältnis). Sensitivität, Spezifität und Aussagekraft der Ultraschallparameter wurden berechnet (Tabelle I). Die klinische Diagnose sowie die Ultraschalldiagnose beider Perioden wurden miteinander verglichen, um den Effekt der Bestimmung der fetalen Umfänge auf die diagnostische Genauigkeit zu analysieren. Die Neugeborenen der 100 Patientinnen aus der prospektiven Studie wurden nach Geburtsgewicht in zwei Gruppen eingeteilt. Alle Kinder mit einem Geburtsgewicht unter der zehnten Perzentile in der Leroy-Lefort Kurve wurden als „small for date“ (SGA) eingestuft. Dies ergab 49 eutrophe Kinder sowie 51 SGA-Kinder. $59 \%$ der SGA's waren vor der Geburt klinisch diagnostiziert worden, $100 \%$ mit dem Ultraschall (Abb. 1). Von den 49 eutrophen Kinder (AGA) waren mit dem Ultraschall sechs falsch positiv eingestuft worden. Benutzt man für die Ultraschallmessung den Umfang des Abdomens, erreicht die diagnostische Analyse eine Sensitivität von $100 \%$ und eine Spezifität von $88 \%$ (Tabelle I).

Wenn wir beide Perioden vergleichen und die klinischen Daten sowie die Ergebnisse der Ultraschalluntersuchungen analysieren, erhalten wir folgende Ergebnisse (Tabelle II): klinische Diagnose in $27 \%$ während der ersten Periode und in 59\% während der zweiten Periode; Messung der fetalen Umfänge mittels Ultraschall, besonders die Messung des abdominalen Umfanges, erhöht die Genauigkeit der Methode von $58 \%$ auf $100 \%$ (signifikanter Chi Quadrat Test). Die mit Messung der Durchmesser gewonnene diagnostische Genauigkeit ist die gleiche für beide Perioden. Der Einsatz der Umfangsmessung ist für den Zuwachs an Genauigkeit verantwortlich.

Schlüsselwörter: Abdominaler Umfang, Ultraschalldiagnostik, klinische Diagnose, intrauteriner Minderwuchs.

\section{Résumé}

Suivi longitudinal de 100 patients à risque de retard de croissance intra-utérin: Comparaison du diagnostic au cours de deux périodes

Le concept de petit poids de naissance comprend deux entités différentes: la prématurité et le retard de croissance intra-utérin. Les deux représentent des problèmes importants en santé publique car ils augmentent la morbidité et la mortalité périnatales [22]. Le diagnostic précoce de R.C.I.U. permet de prendre des décisions appropriées qui rendent possible une diminution de la morbidité et de la mortalité périnatales. Les méthodes cliniques ont fait la preuve de leurs insuffisances pour faire un diagnostic précoce du R.C.I.U. L'échographie offre une aide importante à ce diagnostic, en permettant la mesure des diamètres et des périmètres fœtaux. Cette étude, effectuée pour comparer les deux méthodes, a été réalisée à l'Hopital Antoine Béclère, Clamart, France. Le traitement des données a été effectué au CLAPAHO/WHO.

Sur une première période, l'analyse retrospective de $\mathbf{1 1 6}$ histoires cliniques de R.C.I.U. a été effectuée. Pour cette étude, seul les diamètres fotaux ont été utilisés et on a évalué la fiabilité du diagnostic clinique et du diagnostic échographique. Sur une deuxième période, on a réalisé l'étude prospective longitudinale du suivi de 100 femmes enceintes à risque de présenter un R.C.I.U. On a évalué le diagnostic clinique en le comparant à l'éc̀hographie. Les paramètres utilisés étaient les diamè- tres et les périmètres fœtaux (périmètres céphalique et abdominal, et leurs corrélations). On a calculé la sensibilité, la spécificité et la valeur prédictive des paramètres échographiques (tableau I). On a comparé les diagnostics cliniques et échographiques des deux périodes afin d'analyser les effets des périmètres fœtaux sur la fiabilité du diagnostic. On a classé en deux groupes selon le poids de naissance, les nouveaux-nés des 100 patientes de l'étude prospective. On a considéré comme hypotrophiques tous les nouveaux-nés avec un poids de naissance inférieur au 10ème percentile sur les courbes de Leroy-Lefort. Il y a eu 49 nouveaux-nés eutrophiques et 51 hypotrophiques. Cinquante neuf pour cent des 51 hypotrophiques ont eu un diagnostic clinique prénatal. Le diagnostic échographique a été porté dans $100 \%$ des cas. Parmi les 49 nouveaux-nés eutrophiques, 6 étaient des faux positifs échographiques. L'analyse des diagnostics donne une sensibilité de $100 \%$ et une spécificité de $88 \%$ lorsqu'on utilise pour l'examen échographique la circonférence abdominale fœtale (tableau I).

Si l'on compare les deux périodes diagnostiques et si l'on analyse les données cliniques et échographiques, nous obtenons les résultats suivants (tableau II): le diagnostic a été porté cliniquement dans $27 \%$ des cas au cours de la première période et dans $59 \%$ des cas au cours de la deuxième période; le diagnostic échographique fondé sur les circonférences fotales (tout particulièrement l'analyse de la circonférence abdominale) aug- 
mente la sensibilité de $58 \%$ à $100 \%$ (test du $\chi^{2}$ significatif). Le pourcentage de diagnostic obtenu par l'étude des diamètres est le même pour les deux périodes. L'utilisa- tion des mesures de circonférences entraîne une augmentation de la sensibilité de la méthode.

Mots-clés: Diagnostic clinique, diagnostic échographique, périmètres abdominaux, retard de croissance intrautérin.

Acknowledgements: I wish to express my acknowledgement to all the personnel of the Clinique de Gynécologie et d'Obstétrique du l'Hôpital Antoine Béclère and especially, to Prof. EMILE PAPIERNIK and to all the people of CLAP. I also wish to express my acknowledgement to Dr. RICARDo HORACIO FESCINA (CLAP-OPS/OMS) for the assistance in preparing this paper.

\section{References}

[1] CAmpBell S: An improved method of fetal cephalo metry by ultrasound. J Obstet Gynaecol Br Cwlth 75 (1968) 568

[2] Campbell S, GB Newman: Growth of the foetal biparietal diameter during normal pregnancy. J Obstet Gynecol Br Cwlth 78 (1971) 513

[3] Campbell S, C Dewhurst: Diagnosis of the small for date foetus by serial ultrasonic cephalometry. Lancet 2 (1971) 1002

[4] CAMpBell S, D WiLKIN: Ultrasonic measurements of foetal abdomen circumference in the estimation of foetal weight. Br J Obstet Gynaecol 82 (1975) 689

[5] Campbell S, A Thoms: Ultrasound measurement of the foetal head to abdomen circumference ratio in the assessment of growth retardation. Br J Obstet Gynecol 84 (1977) 165

[6] Fescina RH, FJ UCIEDA: Reliability of foetal anthropometry by ultrasound. J Perinat Med 8 (1980) 93

[7] Fescina RH, FJ UCIEDA, MC CORdano: Ultrasonic patterns of intrauterine foetal growth in a Latin American country. Early Hum Dev 6 (1982) 239

[8] Fescina RH, M Martell, G Martinez, L Lastra, R SCHWARCZ: Small for dates: Evaluation of different diagnostic methods accepted for publication in: Acta Obstet Gynecol Scand 66 (1987) 221

[9] Grall FR: Hypotrophie foetale. Encyclopédie Médicine Chir. Obstétrique 3 (1976) $5076 \mathrm{E}^{10}$

[10] Houlton MCC, M Marivate, RH Philpott: The prediction of foetal growth retardation in twin pregnancy. Br J Obstet Gynaecol 88 (1981) 264

[11] KURJAK A, B BREYER: Estimation of foetal weight by ultrasonic abdominometry. Am J Obstet Gynecol 125 (1976) 962

[12] Kurjak A, K Pertti, V Latin: Biometric and Dynamic ultrasound assessment of small for dates infants: Report of 260 cases. Obstet Gynecol 56 (1980) 281

[13] KuRJaK A, V Latin, J PolaK: Ultrasonic recognition of two types of growth retardation by measurements of four foetal dimensions. J Perinat Med 6 (1978) 102
[14] Leroy B, F Lefort: A propos du poids et de la taille des nouveaux nes a la naissance. Rev Fr Gynecol 66 (1971) 381

[15] LubChenko L, D SeARle, J BraziE: Neonatal morbidity rate: relationship to birth weight and gestational age. J Pediatr 81 (1972) 814

[16] Mann L, N Tejani, R Weiss: Antenatal diagnosis and management of the small for gestational age foetus. Am J Obstet Gynecol 120 (1974) 995

[17] O'Brien G, J Queenan, S Campbell: Assessment of gestational age in the second trimester by real time ultrasound measurement of the femur length. Am J Obstet Gynecol 139 (1981) 540

[18] O'BRIEN G, J QuEENAN: Ultrasound fetal femur length in relation to intrauterine growth retardation. Am J Obstet Gynecol 144 (1982) 35

[19] PAPIERNIK E: Comparison between clinical diagnosis and ultrasonic measures of poor intrauterine fetal growth. Hopital Antoine Béclère, Faculté de Médicine, Paris Sud., 1977. Personal communication

[20] Persson B, M Stangenberg, NO Lunell, U BroDIN, NG Holmberg, V Vaclavinkova: Prediction of size of infants of birth by measurement of symphysis fundus height. Br J Obstet Gynaecol 93 (1986) 206

[21] VILLAR J, JM Belizan: The relative contribution of prematurity and fetal growth retardation to low birth weight in developing and developed societies. Am J Obstet Gynecol 143 (1982) 793

[22] YeRUShalmy J: Relation of birth weight, gestational age and the rate of intrauterine growth to perinatal mortality. Clin Obstet Gynecol 13 (1970) 107

Received November 30, 1986. Accepted February 9, 1987.

Maria Cristina Cordano

Centro Latinoamericano de

Perinatología y Desarrollo Humano

Casilla de Correo 627

Hospital de Clinicas, piso 16

Montevideo, Uruguay 